\section{SCIENTIFIC RESEARCH IN INDIA}

TOWARDS the end of 1943, Prof. A. V. Hill, one of the secretaries of the Royal Society, was invited by the Government of India to visit that country and discuss the organization of scientific and industrial research as part of the Indian post-war reconstruction plan, and its co-ordination with corresponding activities in Britain. Advice was also sought on current research problems, with visits to universities and other research centres. Prof. Hill was thus enabled to obtain a view of the position and progress of science and industry in India more comprehensive than has been vouchsafed to anyone since the examination of the industrial resources of the country carried out by the Indian Industrial Commission under the chairmanship of Sir Thomas Holland during the War of 1914-18.

That Prof. Hill took full advantage of this opportunity is apparent from his report, which has recently been published in India*. From the preface it is seen that the author regards this document rather as a logbook than as a formal or complete report. The material of the original logbook has, however, been regrouped into appropriate sections. These are necessarily many in number, so that to give a brief account of this important public document it seems desirable to mention the substance of each section, omitting Section 1, the Introduction.

Section 2. Lack of Scientific Liaison; and Section 4. An Indian Scientific Office in London.

In spite of the absence of scientific and technical liaison between India and Britain hitherto, Prof. Hill finds that there is a complete lack of any spirit of isolationism on the part of Indian scientific, technical, and medical men, and a frank recognition of the advantages of co-operation. To assure a liaison in the future, he proposes the establishment in London of an Indian Scientific Office with specialists in agriculture, defence, engineering, industry and medicine. This would follow a recommendation of the British Commonwealth Science Committer set up by the Royal Society :

"That a suggestion be made to the Governments of the various English-speaking countries that they should consider the possibility of maintaining permanent scientific representation in London and possibly also in other capital cities of the Eriglishspeaking world".

The Royal Society is prepared to set up a special committee of its fellows for the purpose of advising the Indian Scientific Office, the India Office, or the Office of the High Commissioner for India, on any special matter desired, for example on the filling of important scientific posts in India when suitable men are not available in India.

Section 5. Scientific Liaison with the United States.

India has many problems in common with the United States; for example, dust, erosion, floods, rural health and nursing services, control of pests, irrigation and hydro-electric developments. The British Central Scientific Office established in Washington since 1941 acts now for the Dominions as well as for the United Kingdom, and the attachment of representative Indian men of science to this office would be welcomed both by the director thereof and by the Americans.

- Scientiflc Research in Irdia. By Prof. A. V. Hill. Pp. 40. (Simla : Government of India Press, 1944.)
Section 3. Research Training of Young Indians in the United Kingdom.

India has been largely cut off intellectually for nearly five years from the rest of the world, and it is urgently necessary to resume and enlarge arrangements that existed before the War for advanced study abroad, especially in Britain, by young Indian teachers, research workers, and members of technical staffs. On the other hand, the universities, medical schools, technical colleges, and research laboratories of Britain will be overwhelmed after the War with applications from others whose claims it will be difficult to resist. This means that there will be a severe competition for such facilities, and it will be imperative that the Indians sent overseas should be carefully selected. Such training will have to be financed by Government; but as Prof. Hill points out, there should be no difficulty over this as the sterling balance of India in Great Britain is already about $£ 1,000$ millions.

\section{Section 6. A Research Background in Medical Educa-} tion.

As a physiologist, Prof. Hill was given special opportunities of seeing hospitals, medical colleges, and departments of medical science. His general criticism of medical education in India is that there is little significant research done at the medical colleges either in $(a)$ the pre-clinical sciences (anatomy, pharmacology, physiology, cr normal psychology), in (b) pathology and bacteriology, or in (c) clinical science. The fundamental cause in each case is that departments are much understaffed; and of such staff as there is, most are only part-time employees of the colleges, depending usually on private practice for the major portion of their income. Prof. Hill cites the report of the Goodenough Committee in Britain as to the staff necessary for the various departments of a university medical centre; but he realizes that nothing on the same scale can be done in India at present, except at one or two centres, because there are not enough people of sufficiently high standard available. Also there would probably be considerable opposition to the full-time principle. Further, the universal adoption of provision for medical education on the scale suggested is bound to be very expensive.

\section{Section 7. An All-India Medical Centre.}

Recognizing the importance to any country of a really high type of medical practitioner and of a high type of medical teacher and research worker, Prof. Hill advocates the establishment of an All-India Medical Centre, staffed in all departments by the ablest people available anywhere, employed full-time and adequately paid. To attain this end, liberal expenditure on scholarships will be required. Further, in order to avoid communal, political, inter-provincial, and inter-State rivalries and jealousies, this Centre must be established at Delhi. It is desirable, if possible, that it should be built, equipped and endowed entirely from voluntary gifts, so as to strengthen its hand against eventual political or other pressure, and Prof. Hill suggests that such an All-India Medical Centre might be a very fitting national memorial to the Indian Forces after the War.

As malaria in India is the most serious publio menace, Prof. Hill suggests that as part of this All. India Medical Centre there should be a special hospital for the clinical study of malaria. 
Section 8. Medical Research.

Although medical colleges in India generally lack the research atmosphere for reasons already given, yet India has a high reputation for medical research, especially into tropical diseases (for example, malaria, cholera, plague, and kala-azar). This work has been done in the main at special institutes, for which the research department of the Indian Medical Service has been mainly responsible, helped by grants and salaries provided by the Indian Research Fund Association. The latter is an independent registered body drawing its funds from a 'user' department of the Government of India (Education, Health, and Lands). It should rank with the Medical Research Council in Great Britain, but does not because of the inadequacy of its funds. Prof. Hill would like these medical research institutes, where practicable, to be brought into closer contact with medical colleges and higher medical education, to the mutual benefit of both; this should also be borne in mind when new medical research units are planned.

Since the object of medical research is treatment of the sick and improvement of public health, it may help to give some idea of the magnitude of the medical and health problems before India if the reviewer intercalates here a comparison made for another purpose of the financial provision for medical and health purposes in India and Malaya respectively. In 1938 the provision in the Federated Malay States estimates under 'Medical and Health' was 2.43 dollars (Rs. 4-4-0) per head or 180 dollars per square mile. In India the expenditure on medical relief in twelve provinces varied in 1936 from one anna per head in the United Provinces to 8 annas 8 pies in Baluchistan. For Madras alone, from which the Tamil population of Malaya is largely derived, the figures were 2 annas 7 pies per head and Rs. 53 per square mile. Thus for Madras the provision per person was only one twenty-sixth of that in the Federated Malay States, while measured by area it was one sixth.

[Straits dollar $=2 s .4 d . \quad$ Rupee $=1 s .6 d$.

\section{Section 9. Vital Statistics and Population.}

Prof. Hill directs attention to the rapid increase in the population of India and to the fact that improved public health and nutrition, and diminution of the present high mortality, will cause the population to increase at a still higher rate, at least for some time ; also that, contrary to what is commonly thought, industrialization, with a resultant higher standard of living, may at first also cause a rise in the birth-rate. As the decision regarding the direction in which the available effort for national development should be applied depends largely upon a public understanding of the facts and probable trends of morbidity, mortality, reproduction, and population, more accurate data on these points, and their more detailed analysis, are required.

\section{Section 10. Agricultural Research.}

Agriculture is India's most important industry, but great expansion is necessary, first to provide more adequate nutrition for the present population of some 400 millions, secondly to anticipate the needs of the expected increase of population, and thirdly to provide for the expansion of crops required for industry and export.

Excellent work is being done in India in agricultural research by a variety of organizations maintained both centrally and provincially and by Indian
States. Nevertheless, the total expenditure is only two thirds of that in Great Britain before the War on agricultural research, although Great Britain has only one eighth the population and one twentieth the area. The expenditure in India is still only about one quarter of an anna per person per annum, and one tenth of an anna per acre of the total area.

\section{Section 11. Surveys and Natural Resources.}

The great natural resources of India are still inadequately known. Consequently the Geological Survey must be expanded, the Botanical Survey restored, and the Zoological Survey extended. The proposed research institutes on marine and freshwater fisheries should be set up as soon as possible. Other subjects, such as water-power, water-supply, forests and soil, require fuller investigation. A central research board for surveys and natural resources is recommended.

Section 12. Industrial Research under the Government.

The Board of Scientific and Industrial Research founded in 1940 has already produced important results, but the headquarters staff assisting the Director of Scientific and Industrial Research is far too small. It will be important for this Board to be in close and familiar contact with the Department of Scientific and Industrial Research in Britain and with corresponding bodies in the Dominions.

\section{Section 13. Scientific Research by Industry.}

Examples are given of the giant research organizations maintained in the United States and Britain by some of the leading industrial organizations; for example, the Bell Telephone Laboratories in New York, the Eastman Kodak at Rochester, N.Y., the G.E.C. at Wembley, Imperial Chemical Industries, Ltd., Burroughs Wellcome, Lever Bros., and various engine and aircraft firms. In addition to these many private enterprises of individual firms in Britain, there are twenty-four industrial research associations maintained jointly by industry and the Department of Scientific and Industrial Research.

In India the nearest approach to the American and British model is the Metallurgical Laboratory of the Tata Iron and Steel Co. Admitting that India as a whole is poor, and that the number of men capable of the requisite effort in any field is very limited, Prof. Hill thinks that Indian industry is not yet making nearly the research effort it could on its own behalf, especially as some of its industries have recently been prospering exceedingly.

\section{Section 14. Technology.}

In Great Britain there is as yet no institution comparable in magnitude, in the quality of equipment and in excellence of teaching and research work with the Massachusetts Institute of Technology at Cambridge, Mass.; the view is held in Britain that two or three such institutions should be set up, or that existing institutions should be expanded for the purpose, at such centres as Glasgow, Manchester, Birmingham and London. This being the view held in a country where, after all, the conditions are not so bad, how much more can we recognize the necessity for one or two such institutes or colleges of very high standard in India? For the future of Indian industrial and agricultural development must depend on the supply of first-class technical brains, trained in an atmosphere of original research and practical 
experience. Of existing organizations, the Indian Institute of Science at Bangalore comes closest to what is wanted. One chief purpose of the proposed new institutes of technology would be to provide teachers and research workers of high quality for other places.

\section{Section 15. Meteorological Research.}

The requirements of the Fighting Services and particularly of the Air Force, and the needs of civil aviation, have expanded greatly the usefulness of the India Meteorological Department; but meteorology has many other applications; for example, in radio and, in India particularly, in agriculture and in emergency warning of floods. Proposals have been made to the Board of Scientific and Industrial Research for the further development of fundamental research in meteorology in India, and these proposals have been accepted.

\section{Section 16. Scientific Instruments and Equipment.}

This is a key industry, and urgently needs encouragement. Given training and experience, Indian workmen have all the natural aptitudes for such manufacture (as has been demonstrated for many years by the Survey of India).

Section 17 Post-War Disposal of Government Stock.

A considerable amount of scientific and medical equipment and machine tools will be available after the War. Prof. Hill recommends that a free distribution should be made to university and other institutions of the equipment they require; for one of the most obvious criticisms of the majority of university laboratories in India refers to the poverty of their scientific equipment and the frequent absence of any proper workshop facilities and tools.

\section{Section 18. Research for Fighting Services.}

The existing research organization of the Defence Services in India was not designed for the contingency of India being the base for major naval, military and air operations. Any improvements that can now be made in the arrangements for research in connexion with the Services should be planned not only for the present War, but also in view of the future necessity of the Government of India under a new constitution taking full responsibility for her own defence. Prof. Hill proposes a War Research Board in liaison with a Central Organization for Scientific Research.

\section{Section 19. A Central Organization for Scientific} Research.

This is the most important section of Prof. Hill's report, because it contains constructive proposals for remedying the various shortcomings in the provision for scientific, medical, and industrial research that his survey has brought to his notice. Prof. Hill first enumerates and describes the various coordinating research bodies set up in Britain, namely, the Medical Research Council (1914), the Department of Scientific and Industrial Research (1916), the Agricultural Research Council (1931), and the War Cabinet Scientific Advisory Committee (1940). He proposes for India a Central Organization for Scientific Research working under the Honorable Member for Planning and Development, to control and coordinate six research boards, namely, medical, agricultural, industrial, engineering and war, and a board of surveys and natural resources.
Section 20. A Central Register of Scientific and Industrial Personnel.

'The Scientific Section of the Central Register in Britain has proved of much value in selecting scientific and technical personnel for work connected with the war effort. It is regarded now as an institution of permanent value to the country; but how it will be organized and used in peace-time has not been decided. Prof. Hill considers that a similar register would be of use to India, and has suggested that the National Institute of Sciences of India should undertake its construction. The Board of Scientific and Industrial Research has made a suitable grant to the National Institute for this purpose.

\section{Section 21. Pay and Status of Scientific Workers in} Government Service.

One of the defects of employment in Government service both in Britain and India is that the administrator is usually much more highly paid than the scientific or technical man of the same standing, experience, training and ability, so that the scientific man has been unable to attain more than a very limited position and salary without undertaking administrative work. This difference requires modification if Government is to secure the ablest men in science and give them the best opportunities for developing and using their talents.

\section{Section 22. Scientific Societies in India.}

Prof. Hill points out that scientific societies are of two kinds, general and special, and that both kinds have an important part to play in the publication of scientific papers and results as well as in the formation of libraries and collections. "Scarcely less important is their influence in making living communities out of a number of people always critical and often highly individualist. In India where so many causes tend at present to separate individuals, groups and com. munities from one another a strong common interest in science as a whole, or in some branch of it, could have as a bye-product an important influence in keeping people working sensibly together". Prof. Hill outlines some of the ways in which these societies could be assisted and encouraged by Government without diminution of their independence. Once the National Institute of Sciences of India has been formally recognized as fulfilling in India functions similar to those of the Royal Society in Britain, it will be available to take up various matters with Government on behalf of sister societies, and to distribute Government grants for certain scientific purposes, such as grants for publications, and grantsin-aid for scientific investigations and for international scientific conferences. A beginning has been made by entrusting the National Institute with grants for publications and for the preparation of a Central Scientific Register.

\section{Section 23. Scientific Research in Indian Universities}

This subject would require long and careful study and a small commission under a scientific man as chairman might well be appointed to study the whole subject. Meanwhile, Prof. Hill remarks that scientific research in the universities, both for its own sake. and as a background for scientific education, is the fundamental basis of all scientific progress. The most notable contributions of Indian men of science have been in physics, mathematics and chemistry, and there are in fact a good many strong departments in 
physics and chemistry at Indian universities. But in the biological sciences and in geology, the departments, where they exist, are nearly always small, ill-equipped and under-stafled. Even allowing for the founding of a few colleges of technology, there will be a need for universities to maintain departments in engineering of a sufficient standard to meet the ordinary needs of industry and public works. Last year the Royal Society set up a number of special committees to investigate the post-war needs of fundamental research in the United Kingdom. Similar investigations would be valuable in India.

\section{Section 24. Private Benefactions in Science.}

Although substantial benefactions have been made to science, medicine and technology in India from private sources, particularly by the Tatas, yet most scientific work in India derives its financial support from the Government. There are in India many rich men who could easily contribute substantially to scientific research. What are specially needed are scholarships, which if endowed could commemorate the names of the donors, on the parallel of the numerous endowed scholarships, studentships, and fellowships in Britain and the United States. There are already in India a few completely non-official privately endowed scientific institutions, for example, the Indian Association for the Cultivation of Science and the Bose Institute in Calcutta, and the Tata Memorial (Cancer) Hospital in Bombay. Here is a great opportunity for Indian benefactors.

\section{BIOLOGY TEACHING IN SCHOOLS AND UNIVERSITIES}

$\mathrm{O}$ March 24 the Association of British Zoologists met in the rooms of the Zoological Society of London, with Prof. James Ritchie in the chair. The morning session was devoted to a discussion of the interrelationship of biology teaching in schools and universities.

In opening the discussion, Dr. C. F. A. Pantin directed attention to the ultimate objects of a biological training. The first duty of a university biological department is to advance knowledge. The depletion during the War of university staffs in zoology has shown how serious the situation could become when research ceases and when individuals with expert knowledge in special fields cease to be available. The training of able students for university posts is essential. Nevertheless, the numbers required each year are few, and the vast majority who receive biological training at a university aim at some other professional career such as teaching in schools.

Important as biology is in education, one would not wish to produce biological instructors simply for the sake of training yet more. In the past, preliminary training for medicine occupied the largest number of zoological students who aimed at other careers, though their contact with the subject was brief. Only a few zoologists were absorbed into other professions. But one hopes to see in the future a steady and increasing demand for careers in veterinary work, agricultural entomology, fisheries in Britain and in the Colonies, as well as in special activities such as the protection of stored products and the prevention of fouling of ships.
It is probable that more zoologists will be required for professional or Government services than for industry. The problems of applied biology are rarely narrow and local. They may cover the whole country and may lead into physics, chemistry, mathematics and even more distant studies like sociology. There is little scope for technicians with limited but intensive training comparable to that of the radio expert in physics. The social importance of biological problems is not less for that reason.

However, the War has shown the value in an unexpected direction of the wide training a biologist receives. It has been the common experience that biologists are peculiarly fitted for the varied problems which come under the heading 'operational research'. Their advantage seems to depend on the fact that they are more accustomed than the physicist to hunting for general principles in a mass of apparently unconnected particular instances. The biologist cannot afford to reject any problem just because he is unable to examine and control it at leisure in the laboratory. He must often start with varied, qualitative and above all fugitive data. His problems are often of a kind which a physicist would reject as unsatisfactory for attack. But it is the solution of just this kind of difficulty which is needed in everyday life. We may hope that after the War biological students may find their place, attacking the general problems of industry just as they have attacked those of operational research.

It is clear that the preparation of the young biologist for any career will require a wide and sound scientific training. How far does the present educational system provide this? The universities have often complained that the teaching at school is too specialized : an attempt is made to cover too much ground, so that elementary knowledge is weak and the necessary revision at the university bores the student. It is also claimed that another result of this specialization is lack of general education and inability of the student not merely to read languages other than his own but even to express himself in his mother tongue. 'Though this may be partly true, it is open to question whether the degree of illiteracy among biological students is as great as some have supposed. Another criticism directed at university entrants in biology is that their knowledge of mathematics and physical science is too weak. Many university teachers have been told: "I took up biology because I was no good at physics".

In all these criticisms there is some substance. But from the point of view of the universities, perhaps the most serious criticism of all is that under the present system the standard of knowledge of entrants in biological subjects varies so greatly that the construction of satisfactory preliminary courses at the university becomes extremely difficult. Pessimists have said that the only solution is to begin biological training at the university. They quote the case of the classic who turned over to biology and outstripped the rest of the class. They usually omit to remark that this is only characteristic of men of outstanding ability who would succeed in whatever direction they turned. But, in fact, teaching of biology at schools has come to stay. It must never be forgotten that the majority of school-children are not in fact going on to a university at all, and the case for giving the general citizen an elementary biological training is overwhelming. Moreover, a good school training in biology can be of the very greatest value to the university entrant. Time 